\title{
Aikuisväestön taidot arvioitu 24 maassa
}

\author{
PIAAC-arvioinnin tulokset aikuisväestön taidoista kertoivat suomalaisille \\ PISA-arvioinneista tuttua tietoa: aikuisväestö on lukijoina, laskijoina ja \\ ongelmanratkaisijoina maailman huippuluokkaa. Julkisuudessa esitetyissä \\ kommenteissa kiinnitettiin huomiota taitojen puutteisiin, huonosti \\ menestyneiden osuuksiin ja väestöryhmien välisiin eroihin. Opetusministerin \\ johtopäätös oli: parantaa pitää.
}

TAITOJEN HEIKKO TASO on joissakin maissa saanut poliitikot ja opetushallinnon viranhaltijat huokailemaan pettymyksestä. Selityksiä huonolle menestykselle on jouduttu keksimään PIAAC-arvioinnin tulosten saavuttua lokakuussa 2013. Arviointia kohtaan esitettiinkin jo tuoreeltaan kritiikkiä, joka on tullut tutuksi PISA-arviointien tulosten tultua. Kritiikin kohde on yleensä mittaväline ja sen puolueettomuus. Arvioivaan mittaamiseen liittyy toki laajempiakin kysymyksiä. Arviointi on vallankäyttöä, ja julkistetut rankinglistat eli maiden listaaminen paremmuusjärjestykseen lähes väistämättä johtavaa kilpailun kiristymiseen (ks. Välijärvi 2010; Simola ym. 2013). Listaukset voivat kiihdyttää kilpailua tavalla, joka sopii huonosti yhteen koulun kasvatuksellisten tavoitteiden kanssa. Jo nyt esimerkiksi suomalaiseen "koulubrändiin” kuuluu, että suomalaislapset ja nuoret viih- tyvät koulussa muiden maiden lapsia huonommin. Toisaalta Suomessa koulutyöhön käytetään vähemmän aikaa kuin monissa relevanteissa vertailumaissa.

\section{AIKUISTUTKIMUS PIAAC}

PIAAC-arviointi on osa OECD:n aloitteesta käynnistettyä tutkimusohjelmaa Programme for the International Assessment of Adult Competencies, ja se mittaa aikuisväestön työ- ja arkielämän perustaitojen osaamista ja käyttöä. Nyt raportoituun ensimmäiseen vaiheeseen osallistui 24 maata, ja vuosina 2012-2016 toteutettavaan toiseen vaiheeseen osallistuu yhdeksän uutta maata. Hanke jatkaa siitä, mihin IALS-arviointi (International Adult Literacy Survey) päättyi (ks. Linnakylä ym. 2000).

Tutkimuksen tavoitteena on arvioida, ovatko aikuisten perustaidot sillä tasolla, että he pystyvät 


\begin{tabular}{|l|r|rr|cc|}
\hline Maa & $\begin{array}{r}\text { keski- } \\
\text { arvo }\end{array}$ & $\begin{array}{r}\text { taso 1 } \\
\text { tai alle }\end{array}$ & $\begin{array}{r}\text { tasot } \\
\mathbf{4} \text { ja } 5\end{array}$ & $\begin{array}{c}\text { nuorten ja } \\
\text { vanhojen ero* }\end{array}$ & p-arvo \\
\hline 1. Japani & 296 & 6 & 23 & 25,2 & 0,000 \\
\hline 2. Suomi & 288 & 11 & 22 & 42,1 & 0,000 \\
\hline 3. Alankomaat & 284 & 14 & 18 & 33,4 & 0,000 \\
\hline 4. Australia & 280 & 14 & 17 & 28,5 & 0,000 \\
\hline 5. Ruotsi & 279 & 14 & 16 & 25,8 & 0,000 \\
\hline 6. Norja & 278 & 14 & 14 & 19,6 & 0,000 \\
\hline 7. Viro & 276 & 13 & 12 & 26,0 & 0,000 \\
\hline 8. Belgia (Flanderi) & 275 & 19 & 12 & 28,9 & 0,000 \\
\hline 9. Tšekki & 274 & 13 & 9 & 22,6 & 0,000 \\
\hline 10. Slovakia & 274 & 12 & 7 & 7,2 & 0,003 \\
\hline 11. Kanada & 273 & 18 & 14 & 17,1 & 0,000 \\
\hline Kaikki maat & 273 & 16 & 12 & 24,1 & 0,000 \\
\hline 12. Korea & 273 & 13 & 8 & 38,3 & 0,000 \\
\hline 13. Iso-Britannia (E, PI) & 272 & 17 & 13 & $-2,1$ & 0,553 \\
\hline 14. Tanska & 271 & 16 & 10 & 32,2 & 0,000 \\
\hline 15. Saksa & 270 & 18 & 11 & 39,1 & 0,000 \\
\hline 16. Yhdysvallat & 270 & 22 & 12 & 16,7 & 0,000 \\
\hline 17. Itävalta & 269 & 17 & 8 & 11,6 & 0,000 \\
\hline 18. Kypros & 269 & 30 & 5 & 0,7 & 0,736 \\
\hline 19. Puola & 267 & 19 & 10 & 28,5 & 0,000 \\
\hline 20. Irlanti & 267 & 17 & 8 & 10,9 & 0,000 \\
\hline 21. Ranska & 262 & 22 & 8 & 23,0 & 0,000 \\
\hline 22. Espanja & 252 & 28 & 5 & 32,9 & 0,000 \\
\hline 23. Italia & 250 & 29 & 3 & 22,1 & 0,000 \\
\hline
\end{tabular}

Taulukko 1.

Lukutaito: testipisteiden keskiarvot ja huonojen ja hyvien lukijoiden osuus (\%) sekä nuorten ja vanhojen välinen ero 23 maassa. Venäjän tulokset eivät ehtineet nyt esitettyihin analyyseihin.

*Nuorten ja vanhojen ero perustuu regressiomalliin, joka ottaa huomioon useita tekijöitä: iän, sukupuolen, koulutustason, maahanmuuttajataustan, kielitaustan, sosioekonomisen taustan ja ammattityypin.

Lähde: OECD 2013, taulukot A2.1, A3.1(L). selviytymään nopeiden muutosten mukanaan tuomista tehtävistä. Tutkimuksessa arvioitiin, kuinka hyvin aikuiset hallitsevat kolmea tiedon käsittelyn ja hallinnan avaintaitoa: lukutaitoa, numerotaitoa ja tietotekniikkaa soveltavaa ongelmanratkaisutaitoa. Ihminen tarvitsee näitä taitoja koko elämänsä ajan - työssä, opiskelussa, vapaa-ajan harrastuksissa ja jokapäiväisissä arkitoimissaan. (Ks. Malin 2012; Malin ym. 2013, 8-9.) Varsinaisten testien lisäksi tutkimuksessa kartoitettiin vastaajien taustaan, elämäntilanteeseen ja työhön liittyviä tietoja varsin runsaasti.

Suomessa tutkimuksen toteutuksesta vastasivat Jyväskylän yliopiston Koulutuksen tutkimuslaitos ja Tilastokeskus. Koulutuksen tutkimuslaitoksen vastuulla oli tutkimuksen toteutus ja ensimmäisten tulosten raportointi. Tilastokeskus vastasi tutkimuksen tiedonkeruusta, joka alkoi elokuun lopussa 2011 ja päättyi maaliskuun lopussa 2012. Tutkimuksen rahoittivat opetus- ja kulttuuriministeriö sekä työ- ja elinkeinoministeriö. PIAAC-tutkimuksen kansallinen tutkimusjohtaja Antero Malin kirjoitti tutkimuksen viitekehyksestä ja osa-alueista Aikuiskasvatus-lehdessä 2/2012.

\section{LUKUTAITO}

Lukutaito (literacy) määritellään PIAAC:ssa seuraavasti (OECD 2012, 20; Malin 2012, 132): "Lukutaito on kirjoitettujen tekstien ymmärtämistä, arvioimista ja käyttämistä sekä niiden lukemiseen sitoutumista yhteiskuntaelämään osallistumiseksi, lukijan omien tavoitteiden saavuttamiseksi sekä tietojen ja valmiuksien kehittämiseksi." Lukemisen osa-alueita on kolme: (1) tiedon löytäminen ja tunnistaminen tekstistä, (2) tiedon yhdistäminen ja tulkitseminen tai tekstin, osien suhteuttaminen toisiinsa ja (3) tiedon arviointi ja pohdinta.

Testissä mitatun lukutaidon pistemääristä laskettujen keskiarvojen tarkastelu on yksi tapa arvioida väestön lukutaidon taso. Monia muitakin relevantteja tapoja on. Yhteiskuntapoliittisessa katsannossa on mielekästä kysyä esimerkiksi, kuinka suuri on heikkojen lukijoiden osuus väestöstä, tai kuinka suuri osa on erittäin hyviä. Kuinka suuria eroja eri väestöryhmien (ikä-, sukupuoli-, yhteiskuntaluokka-, eri alueilla asuvien ja etnisten ryhmien) välillä on? Tarkastelu tuottaa tietoa, jonka avulla julkinen valta (tai kansalaisyhteiskunta) voi kohdentaa toimenpiteitä. 
Japanilaisten lukutaidot ovat selvästi muiden maiden aikuisten lukutaitoja paremmat (taulukko 1). Kolmen korkeimman sijan maat erottuvat selvästi muista, kuten myös toisistaan. Sen sijaan seuraavina tulevien Australian, Ruotsin ja Norjan keskinäiset erot eivät ole tilastollisesti merkitseviä. Pohjoismaista vain tanskalaiset jäävät arvioitujen maiden keskiarvotuloksen alapuolelle.

Suurten talouksien, kuten Saksan, Yhdysvaltojen, Ranskan, Italian ja Espanjan aikuisväestö ei yllä lukutaidossaan keskimääräiselle tasolle. Espanjassa ja Italiassa yli neljäsosa aikuisväestöstä yltää lukutaidossaan vain alimmalle tasolle 1. Myös Ranskassa ja Yhdysvalloissa huonosti lukevien osuus on huomattavan suuri, reilu viidennes aikuisista. Toisella äärilaidalla japanilaisista vain kuusi prosenttia jää ykköstasolle. Japanilaisista noin neljännes on erittäin hyviä lukijoita sijoittuen kahdelle ylimmälle taitotasolle (tasot 4 ja 5). Suunnilleen samansuuruinen osuus (22\%) myös suomalaisista aikuisista lukeutuu erinomaisiksi (eli 4/5 tason) lukijoiksi, mutta Suomessa heikkojen (eli 1-tason) lukijoiden osuus on Japania suurempi.

Japanilaiset erottuvat muista maista paitsi parhaan keskimääräisen lukutaidon perusteella myös pienempien lukutaitojen erojen ansiosta. Parhaiden ja heikoimpien välinen ero on selvästi pienempi kuin esimerkiksi Suomessa. Muita verraten pienten erojen maita ovat Tsekki ja Slovakia sekä Kypros.

Nuorten ja vanhojen ikäryhmien välinen lukutaitoero on Suomessa vertailumaiden suurin. Vain Saksassa ja Koreassa ero on edes lähellä Suomen eron suuruutta. Ero vanhojen ja nuorten välillä on lähes kaikissa maissa tilastollisesti erittäin merkitsevä (poikkeuksina Kypros ja Iso-Britannia, joista kummastakin vain osa väestöä on mukana: Kyproksesta kreikkalainen puoli ja Iso-Britanniasta Englanti ja Pohjois-Irlanti). Ruotsissa nuorten ja vanhojen lukutaitoero on keskimääräistä luokkaa ja Norjassa selvästi keskimääräistä pienempi.

Natiivien ja maahanmuuttajien välinen lukutaitoero on suurin Suomessa (53,7 pistettä), Koreassa (54,0 pistettä) ja Ruotsissa (52,9 pistettä).

Yhdessä suhteessa Suomen väestö erottuu edukseen "parhaaksi rankattuun" Japaniin verrattuna: suomalaisten lukijoiden paras viisi prosenttia yltää korkeampaan testipistemäärään kuin japanilaisten (ja myös kaikkien muiden maiden) paras viisi prosenttia. Suomen terävin kärki on myös terävintä koko maailmassa.

\section{NUMEROTAITO}

Numerotaito (numeracy) ja numeerinen toiminta määritellään seuraavasti (OECD 2012, 34; Malin 2012, 133): "Numerotaidolla tarkoitetaan yksilön kykyä hankkia, käyttää, tulkita ja viestiä matemaattista tietoa ja ajattelua, jotta hän hallitsee aikuiselämän matemaattiset vaatimukset. [--] Numeerinen toiminta tarkoittaa todellisen elämän tilanteissa eri tavoin esitettyyn matemaattiseen sisältöön, tietoon ja ajatteluun liittyvän asian hallitsemista tai ongelman ratkaisua." Numerotiedon käsittelyssä erotetaan kolme osa-aluetta: (1) tiedon tunnistaminen ja löytäminen, (2) tiedon käyttäminen, ja (3) tiedon tulkinta, arviointi, analysointi ja viestintä. Numeerinen tieto kuului testeihin monin tavoin: kuvina, numeroina, matemaattisina symboleina, kaavoina, kuvioina, karttoina, taulukoina ja teksteinä.

Numerotaitojen kärki on aika lailla samanlainen kuin lukutaidon kärki. Japanilaiset ovat numerotaidossa selvästi muiden maiden aikuisia etevämpiä (taulukko 2). Sen sijaan seuraavina tulevien suomalaisten, belgialaisten (Flanderin alueen) ja hollantilaisten välillä ei ole merkitsevää eroa. Suomen tapaan muut pohjoismaat sijoittuvat numero-osaamisessa parhaiten menestyvien joukkoon. Ruotsin, Norjan ja Tanskan keskiarvojen välillä ei ole numerotaidossa eroa.

Kärkimaissa tasolle 4/ 5 yltävien osuus on 1-tasolle jäävien osuutta suurempi. Japanissa ja Suomessa korkeimmille tasoille pääsee noin viidennes aikuisista, kun korkeintaan 1-tasolle yltäviä on noin kymmenesosa. Muissakin Pohjoismaissa hyvien numerotaitajien osuus on suurempi kuin heikkojen taitajien.

Numerotaidot jakautuvat Japanissa samoin kuin lukutaito: heikoimpien ja parhaiden ero on pienempi kuin muissa maissa, mitä voidaan pitää myös yhdenlaisena saavutuksena, kunhan vain osaamisen keskiarvo on suhteellisen korkea. Samoin kuin lukutaidossa myös numerotaidoissa paras viisi prosenttia suomalaisista yltää korkeampaan testipistemäärään kuin muiden maiden vastaavat "huiput". 


\begin{tabular}{|l|c|cc|cc|}
\hline Maa & $\begin{array}{c}\text { keski- } \\
\text { arvo }\end{array}$ & $\begin{array}{c}\text { taso } 1 \text { tai } \\
\text { alle }\end{array}$ & $\begin{array}{c}\text { tasot } \\
\text { 4 ja } 5\end{array}$ & $\begin{array}{c}\text { miesten ja } \\
\text { naisten ero }\end{array}$ & p-arvo \\
\hline 1. Japani & 288 & 9 & 19 & 12,3 & 0,000 \\
\hline 2. Suomi & 282 & 13 & 19 & 10,2 & 0,000 \\
\hline 3. Belgia (Flanderi) & 280 & 18 & 17 & 16,0 & 0,000 \\
\hline 4. Alankomaat & 280 & 15 & 17 & 16,7 & 0,000 \\
\hline 5. Ruotsi & 279 & 14 & 19 & 13,6 & 0,000 \\
\hline 6. Norja & 278 & 16 & 17 & 14,8 & 0,000 \\
\hline 7. Tanska & 278 & 14 & 17 & 10,3 & 0,000 \\
\hline 8. Slovakia & 276 & 13 & 13 & 2,4 & 0,070 \\
\hline 9. Tšekki & 276 & 14 & 11 & 9,0 & 0,000 \\
\hline 10. Itävalta & 275 & 16 & 14 & 13,2 & 0,000 \\
\hline 11. Viro & 273 & 14 & 11 & 6,0 & 0,000 \\
\hline 12. Saksa & 272 & 20 & 14 & 17,3 & 0,000 \\
\hline Kaikki maat & 269 & 20 & 12 & 11,7 & 0,000 \\
\hline 13. Australia & 268 & 22 & 13 & 13,7 & 0,000 \\
\hline 14. Kanada & 265 & 23 & 13 & 14,6 & 0,000 \\
\hline 15. Kypros & 265 & 33 & 7 & 7,3 & 0,000 \\
\hline 16. Korea & 263 & 19 & 7 & 10,3 & 0,000 \\
\hline 17. Iso-Britannia (E, PI) & 262 & 25 & 11 & 14,2 & 0,000 \\
\hline 18. Puola & 260 & 24 & 8 & 1,9 & 0,170 \\
\hline 19. Irlanti & 256 & 25 & 8 & 11,9 & 0,000 \\
\hline 20. Ranska & 254 & 29 & 8 & 10,8 & 0,000 \\
\hline 21. Yhdysvallat & 253 & 33 & 8 & 14,1 & 0,000 \\
\hline 22. Italia & 247 & 33 & 5 & 10,7 & 0,000 \\
\hline 23. Espanja & 246 & 32 & 4 & 12,5 & 0,000 \\
\hline
\end{tabular}

Taulukko 2. Numerotaito: testipisteiden keskiarvot sekä korkeintaan tasolle 1 yltävien ja tasolle 4 tai 5 yltävien osuudet (\%) sekä miesten ja naisten välinen ero 23 maassa

Tulokset perustuvat regressiomalliin, joka ottaa huomioon useita tekijöitä: iän, sukupuolen, koulutustason, maahanmuuttajataustan, kielitaustan, vanhempien koulutustason, aikuiskoulutukseen osallistumisen,

lukemisaktiivisuuden työssä ja vapaa-ajalla, numerotaitojen käytön aktiivisuuden työssä ja vapaaajalla, ICT-aktiivisuuden työssä ja vapaa-ajalla.

Lähde: OECD 2013, taulukot $A 2.5$ ja $A 3.4(\mathrm{~N})$

Etelä-Euroopan maiden tapaan Yhdysvallat sijoittuu numerotaidoissa heikompien joukkoon. Näiden maiden aikuisista peräti kolmannes yltää korkeintaan 1-tasolle, mitä on syytä pitää erittäin suurena osuutena. Näissä maissa jatkoanalyysejä tehdään varmasti juuri tästä joukosta. Yhdysvalloissa vain joka kahdestoista yltää numerotaidoissa erinomaiselle tasolle; Italiassa ja Espanjassa joka kahdeskymmenes.

Sukupuolten välinen ero numerotaidoissa miesten hyväksi on noin 12 pistettä. Suomessa ero on jonkin verran keskimääräistä pienempi. Suurin ero sukupuolten välillä on Keski-Euroopan maissa: Saksassa, Belgiassa ja Alankomaissa. Pienimmät sukupuolten väliset erot ovat entisissä sosialistissa maissa, Puolassa, Slovakiassa, Virossa ja Tšekin tasavallassa (sekä Kyproksella).

\section{ONGELMANRATKAISUTAITO}

Ongelmanratkaisutaito tietoteknisessä ympäristössä määritellään seuraavasti (OECD 2012, 47;
Malin 2012, 133-134): ”Ongelmanratkaisutaito tietoteknisessä ympäristössä sisältää digitaalisen teknologian, viestintävälineiden ja tietoverkkojen hyödyntämistä tiedon hankkimisessa ja arvioimisessa, viestinnässä ja käytännön tehtävien tekemisessä. PIAAC:n ensimmäinen ongelmanratkaisututkimus keskittyy taitoihin ratkaista ongelmia henkilökohtaisissa, ammatillisissa ja kansalaisena toimimiseen liittyvissä tilanteissa, joissa edellytetään tarkoituksenmukaisten tavoitteiden asettamista, työskentelyn suunnittelemista sekä sähköisessä muodossa olevan tiedon hankkimista ja käyttämistä.” Testiin osallistuminen siis edellytti tietokoneen käytön hallintaa.

Toisin kuin luku- ja numerotaidot, ongelmanratkaisutaitotestien tulokset luokitellaan kolmelle tasolle, 1-taso on alin ja 3-taso ylin. Joissakin maissa (esimerkiksi Japanissa) suuri osa väestöstä ei osallistunut tietokoneella tehtyyn testiin lainkaan joko taitojen tai rohkeuden puutteen vuoksi (taulukko 3). 


\begin{tabular}{|l|ccc|}
\hline Maa & taso 2 & taso & alle \\
tai yli & 3 & tason 1 \\
\hline 1. Ruotsi & 44 & 9 & 25 \\
\hline 2. Suomi & 41 & 8 & 30 \\
\hline 3. Alankomaat & 41 & 7 & 25 \\
\hline 4. Norja & 41 & 6 & 27 \\
\hline 5. Tanska & 38 & 6 & 29 \\
\hline 6. Australia & 38 & 6 & 33 \\
\hline 7. Kanada & 36 & 7 & 34 \\
\hline 8. Saksa & 36 & 7 & 33 \\
\hline 9. Iso-Britannia (E, PI) & 35 & 6 & 31 \\
\hline 10. Japani & 34 & 8 & 46 \\
\hline 11. Belgia (Flanderi) & 35 & 6 & 26 \\
\hline Kaikki maat & 34 & 6 & 36 \\
\hline 12. Tsekki & 34 & 7 & 38 \\
\hline 13. Itävalta & 32 & 4 & 37 \\
\hline 14. Yhdysvallat & 31 & 5 & 36 \\
\hline 15. Korea & 31 & 4 & 40 \\
\hline 16. Viro & 27 & 4 & 44 \\
\hline 17. Slovakia & 26 & 3 & 46 \\
\hline 18. Irlanti & 25 & 3 & 46 \\
\hline 19. Puola & 19 & 4 & 62 \\
\hline
\end{tabular}

kohtuullisella - tavalla selviytymään ongelmanratkaisusta tietoteknisessä ympäristössä.

\section{Taitojen lisääntyminen koulutustaso mukaan}

Korkea-asteen koulutuksen saaneista parhaiten lukutaitotestissä pärjäävät australialaiset, ruotsalaiset, japanilaiset ja hollantilaiset (taulukko 4). Muut maat tulevat kauempana tämän kärkijoukon jäljessä. Seuraavassa aallossa ovat Iso-Britannia ja Suomi. Maailman arvostetuimpien yliopistojen maassa Yhdysvalloissa korkeakoulutetut saavat keskimäärin noin 20 pistettä vähemmän kuin kärkinelikon korkeakoulutetut. Keskiasteen suorittaneiden ja perusasteen varassa olevien keskiarvojen mukainen järjestys on parhaiten menestyneiden maiden osalta suunnilleen samanlainen.

Toinen mielenkiintoinen havainto taulukosta 4 on, että pelkän perusasteen koulutuksen varassa olevat australialaiset, ruotsalaiset, japanilaiset ja hollantilaiset menestyvät lukutaitotestissä keskimäärin yhtä hyvin kuin korkeakoulutuksen saaneet Espanjassa, Koreassa, Puolassa, Virossa ja muissa heikosti menestyneissä maissa. Myös esimerkiksi keskiasteen suorittaneet suomalaiset menestyvät yhtä hyvin. Mutta taulukon 4 kärkimaassa Australiassa keskiasteen suorittaneet yltävät samaan pistemäärään kuin korkeakoulutetut Suomessa.

Korkea-asteen ja perusasteen suorittaneiden pistemäärien erotus maittain antaa viitteitä siitä, kuinka paljon osaamista koulutus tuottaa. Keskimäärin korkeakoulutettujen ja perusasteen koulutuksen varassa olevien lukutaitoero on 29 pistettä. Suomessa tällä tavoin arvioitu koulutuksen vaikutus on jonkin verran keskimääräistä pienempi. Selvästi pienempi se on Italiassa $(21,5)$, Australiassa $(24,5)$ ja Norjassa $(24,9)$.

Lukutaitotestissä toiseksi parhaiten menestyneet ruotsalaiset korkeakoulutetut menestyvät parhaiten numerotaitotestissä (taulukko 5). Toiseksi sijoittuvat japanilaiset. Sen sijaan suomalaiset jävät pistemäärissä selvästi jälkeen kärkijoukosta, ja sama näkyy myös keskiasteen suorittaneiden kohdalla. Erot ovat verraten suuret, joskin suomalaiset korkeakoulutetut ovat jonkin verran keskitasoa parempia, mutta keskiasteen suorittaneet" vain" keskitasoa. 


\begin{tabular}{|c|c|c|c|c|}
\hline \multirow[t]{2}{*}{ Maa } & \multicolumn{3}{|c|}{ Koulutusaste } & \multirow{2}{*}{$\begin{array}{c}\text { Korkea- ja } \\
\text { perusasteen } \\
\text { ero }\end{array}$} \\
\hline & Korkea & Keski & Perus & \\
\hline 1. Australia & 334,5 & 322,8 & 310,0 & 24,5 \\
\hline 2. Ruotsi & 333,9 & 315,8 & 301,9 & 32,0 \\
\hline 3. Japani & 333,7 & 318,2 & 303,7 & 30,0 \\
\hline 4. Alankomaat & 332,1 & 317,7 & 301,6 & 30,5 \\
\hline 5. Englanti (UK) & 322,2 & 315,5 & 294,7 & 27,5 \\
\hline 6. Iso-Britannia (E, PI) & 322,0 & 315,1 & 294,3 & 27,7 \\
\hline 7. Suomi & 320,5 & 303,6 & 293,9 & 26,6 \\
\hline 8. Norja & 318,6 & 302,0 & 293,7 & 24,9 \\
\hline 9. Saksa & 313,8 & 299,4 & 282,6 & 31,2 \\
\hline Maiden keskiarvo & 313,6 & 299,7 & 284,2 & 29,4 \\
\hline 10. Kanada & 313,2 & 299,5 & 277,2 & 35,0 \\
\hline 11. Belgia (Flanderi) & 313,0 & 294,0 & 278,0 & 35,0 \\
\hline 12. Pohjois-Irlanti (UK) & 312,7 & 303,5 & 281,3 & 31,4 \\
\hline 13. Yhdysvallat & 312,6 & 292,1 & 277,9 & 34,7 \\
\hline 14. Irlanti & 310,3 & 297,8 & 277,4 & 32,9 \\
\hline 15. Itävalta & 309,1 & 293,0 & 280,4 & 28,7 \\
\hline 16. Tanska & 308,6 & 295,6 & 282,2 & 26,4 \\
\hline 17. Italia & 305,3 & 300,9 & 283,8 & 21,5 \\
\hline 18. Espanja & 303,5 & 292,3 & 275,3 & 28,2 \\
\hline 19. Korea & 303,2 & 291,1 & 274,8 & 28,4 \\
\hline 20. Puola & 300,0 & 282,2 & 269,9 & 30,1 \\
\hline 21. Slovakia & 299,6 & 291,5 & 270,9 & 28,7 \\
\hline 22. Viro & 299,3 & 289,2 & 274,1 & 25,2 \\
\hline 23. Tsekki & 298,0 & 279,6 & 264,1 & 33,9 \\
\hline 24. Kypros & 290,3 & 276,9 & 262,1 & 28,2 \\
\hline
\end{tabular}

\begin{tabular}{|c|c|c|c|c|}
\hline \multirow[t]{2}{*}{ Maa } & \multicolumn{3}{|c|}{ Koulutusaste } & \multirow{2}{*}{$\begin{array}{l}\text { Korkea- ja } \\
\text { perusasteen } \\
\text { ero }\end{array}$} \\
\hline & Korkea & Keski & Perus & \\
\hline 1. Ruotsi & 338,5 & 317,8 & 301,2 & 37,3 \\
\hline 2. Japani & 334,7 & 321,1 & 298,9 & 35,8 \\
\hline 3. Alankomaat & 332,1 & 317,8 & 300,3 & 31,8 \\
\hline 4. Norja & 329,6 & 310,4 & 296,9 & 32,7 \\
\hline 5. Australia & 325,2 & 312,6 & 299,0 & 26,2 \\
\hline 6. Saksa & 325,0 & 306,9 & 285,4 & 39,6 \\
\hline 7. Belgia (Flanderi) & 324,5 & 305,1 & 287,3 & 37,2 \\
\hline 8. Tanska & 323,6 & 310,4 & 293,2 & 30,4 \\
\hline 9. Suomi & 321,3 & 301,3 & 292,5 & 28,8 \\
\hline 10. Englanti (UK) & 321,0 & 312,3 & 293,0 & 28,0 \\
\hline 11. Iso-Britannia (PI, E) & 320,8 & 312,0 & 292,7 & 28,1 \\
\hline 12. Itävalta & 320,0 & 302,5 & 286,6 & 33,4 \\
\hline Maiden keskiarvo & 316,4 & 301,1 & 282,8 & 33,6 \\
\hline 13. Pohjois-Irlanti (UK) & 312,5 & 302,1 & 279,4 & 33,1 \\
\hline 14. Italia & 311,0 & 311,8 & 293,9 & 17,1 \\
\hline 15. Slovakia & 310,3 & 299,7 & 275,9 & 34,4 \\
\hline 16. Kanada & 309,9 & 292,5 & 269,4 & 40,5 \\
\hline 17. Yhdysvallat & 308,7 & 283,7 & 263,2 & 45,5 \\
\hline 18. Irlanti & 308,0 & 292,9 & 273,5 & 34,5 \\
\hline 19. Tsekki & 306,4 & 283,1 & 261,6 & 44,8 \\
\hline 20. Viro & 303,2 & 291,7 & 273,4 & 29,8 \\
\hline 21. Korea & 299,6 & 283,9 & 264,7 & 34,9 \\
\hline 22. Espanja & 299,6 & 289,8 & 271,4 & 28,2 \\
\hline 23. Kypros & 299,1 & 289,8 & 265,7 & 33,4 \\
\hline 24. Puola & 292,5 & 277,1 & 258,2 & 34,3 \\
\hline
\end{tabular}

Taulukko 4. Lukutaito: testipistemäärien keskiarvot koulutustason mukaan sekä korkea-asteen tutkinnon ja perusasteen suorittaneiden välinen ero (korkeaasteen koulutuksen saaneiden pistemäärien mukainen järjestys)

Lähde: PIAAC taulukko B5.3

Taulukko 5. Numerotaidot: testipistemäärien keskiarvot koulutustason mukaan 23 maassa (korkea-asteen koulutuksen saaneiden pistemäärien mukainen järjestys)

Ks. selitys taulukko 4

Lähde: PIAAC taulukko B5.3

Yhdysvaltain korkeakoulutettujen pistemäärä on noin 30 testipistettä pienempi kuin kärkimaan Ruot$\sin$. Keskiasteen suorittaneiden kohdalla ero on noin 34 ja perusasteen suorittaneiden kohdalla peräti 38 pistettä. Amerikkalaisten testimenestys jää osallistujamaiden keskiarvon alapuolelle.

On ehkä hämmentävää huomata, että ruotsalaiset, japanilaiset, hollantilaiset, norjalaiset ja australialaiset menestyvät ongelmanratkaisussa keskiasteen koulutuksella keskimäärin yhtä hyvin kuin amerik-

kalaiset korkeakoulututkinnon avulla. Toisaalta keskiasteen japanilaiset yltävät samaan pistemäärään kuin korkeakoulutetut suomalaiset, ja perusasteen ruotsalaiset yltävät samaan pistemäärään kuin keskiasteen suomalaiset.

Vaikka amerikkalaiset eivät menesty kovin hyvin koulutustasoittain tehdyssä vertailussa, Yhdysvalloissa korkeakoulutuksen vaikutus taitotasoon (suhteutettuna perusasteen varassa oleviin) on vertailumaiden suurin: 45,5 pistettä. Myös Kanadassa 
(40,5 pistettä) ja Tsekin tasavallassa (44,8 pistettä) koulutustasojen välinen ero on suuri. Sen sijaan Italiassa korkeakoulutus ei näytä tuottavan lisäarvoa ongelmanratkaisukykyinä: ero perusasteen koulutuksen varassa oleviin on vain 17 pistettä. Niin ikään Suomessa koulutuksen vaikutus ongelmanratkaisukykyihin jää keskimääräistä pienemmäksi.

\section{MATKA PISA:STA PIAAC:IIN}

Mielenkiintoa PIAAC-arviointiin eittämättä lisää, että tuloksia voidaan tarkastella yhteydessä aiemmin tehtyihin PISA-arviointeihin.

Kuviossa 1 esitetään samaa ikäkohorttia koskevat pistekeskiarvot vuoden 2000 PISA-arvioinnista. Vertailussa ovat PIAAC:ssa saadut pistekeskiarvot. Vertailua rajoittaa, ettei kaikista PIAAC:iin osallistuneista maista ole PISA-tietoa.

Sirontakuviosta voidaan silmämääräisestikin havaita yhteys kahden testin välillä. Erityisesti kuviossa erottuu suomalaisten sijoittuminen oikeaan ylänurkkaan eli kummassakin testissä korkeat pistemäärät saavien alueelle. Tsekit ja italialaiset ovat menestyneet kummassakin testissä verraten heikosti. Irlantilaisnuoret menestyivät 15-vuotiaina PISA-testeissä kohtuullisen hyvin mutta 12 vuotta myöhemmin PIAAC:issa vertailumaita heikommin.

\section{TAIDOT JA AIKUISKOULUTUKSEEN OSALLISTUMINEN}

On erityisen mielenkiintoista saada tutkittua vertailutietoa lukutaidoltaan eritasoisten kansalaisten osallistumisesta aikuiskoulutukseen. Koulutuksen kasautuminen on sinänsä tuttu ilmiö: jo nuoruusiässä pitkään kouluttautuneet osallistuvat muita enemmän koulutukseen myös aikuisiällä. Taidoissa on kysymys samantyyppisestä ilmiöstä: taidoiltaan "edistyneimmät" lisäävät osaamistaan ahkerimmin. Maiden välillä on tässä kuitenkin huomattavia eroja.

Taulukossa 6 verrataan PIAAC:in lukutaitotestissä tasoille 1-5 sijoittuneiden aikuiskoulutukseen osallistumisen "todennäköisyyttä" ( odds ratiot) verrattuna alle 1-tason jääneiden osallistumiseen. Kaikkien PIAAC:iin osallistuneiden maiden tiedoista lasketut arvot osoittavat, että keskimäärin ylimmän lukutaitotason (tasot 4/5) joukko osallistuu aikuis- koulutukseen kolminkertaisella todennäköisyydellä alle 1-tason jäävien osallistumiseen verrattuna.

Saksassa eri taitotasoille sijoittuvien väliset osallistumiserot ovat kaikkein suurimmat: 2-tason taitajat osallistuvat noin kolminkertaisella todennäköisyydellä alle 1-tason jääviin verrattuna; 3 -tason taitajat 4,8-kertaisesti ja ylimmän tason (4/5) taitajat lähes kahdeksankertaisesti. Koreassa, Kanadassa ja Australiassa ero alimman ja ylimmän taitotason välillä on noin viisinkertainen.

Pohjoismaisessa katsannossa Norja osoittautuu aikuiskoulutusta tasaisimmin jakavana maana. Alimman ja ylimmän tasoryhmän välinen ero on vain puolitoistakertainen. Myöskään Suomessa ero ei ole kovin suuri $(\mathrm{OR}=2,3)$. Ruotsissa ero on niin ikään keskimääräistä pienempi. Norjan, Suomen ja Ruotsin keskimääräistä pienemmät osallistumiserot kuvannevat osaltaan aikuiskoulutuspolitiikan pohjoismaista tasa-arvoajattelua.

\section{LOPUKSI}

PIAAC-arviointia johtava ja koordinoiva yhdysvaltalainen Educational Testing Service (ETS) järjesti arvioinnista konferenssin 13.-15. marraskuuta Washingtonissa (PIAAC Invitational Research Conference: The Importance of Skills and How to Assess Them). Siihen osallistui yli kaksisataa tutkijaa ja valtionhallinnon edustajaa. Konferenssissa oli seitsemän perusteellista luentoa, joissa käsiteltiin arvioinnin metodologiaa, tuloksia, aineiston rajoituksia ja mahdollisuuksia, tulevia analyysejä ja aikuisten taitojen arvioinnin tulevaisuudennäkymiä. Kunkin luennon päätteeksi oli perusteellinen kommenttipuheenvuoro ja yleisökeskustelu.

Keskustelua herätti erityisesti koulutuksen osuus taitojen kehittymisessä. Pelkästään koulutusta pidentämällä ei taitotasoa voi nostaa. Siihen tarvitaan taitojen käyttöön ja harjaantumiseen kannustavaa työtä. Lukutaidon käyttö työssä vaihtelee niin ammateittain kuin maittain runsaasti, ja se näkyy myös PIAAC-tuloksissa. Erityisesti lukutaidon tasoon vaikuttaa suhtautuminen lukemiseen ja "lukutottumukset" niin työssä kuin vapaa-ajalla.

Konferenssin esitelmistä kävi hyvin ilmi työn mittavuus sekä suunnittelu- että aineistonkeruun 
Kuvio 1. Saman kohortin pistemäärät PISA-arvioinnissa vuonna 2000 ja PIAAC-arvioinnissa vuonna 2012

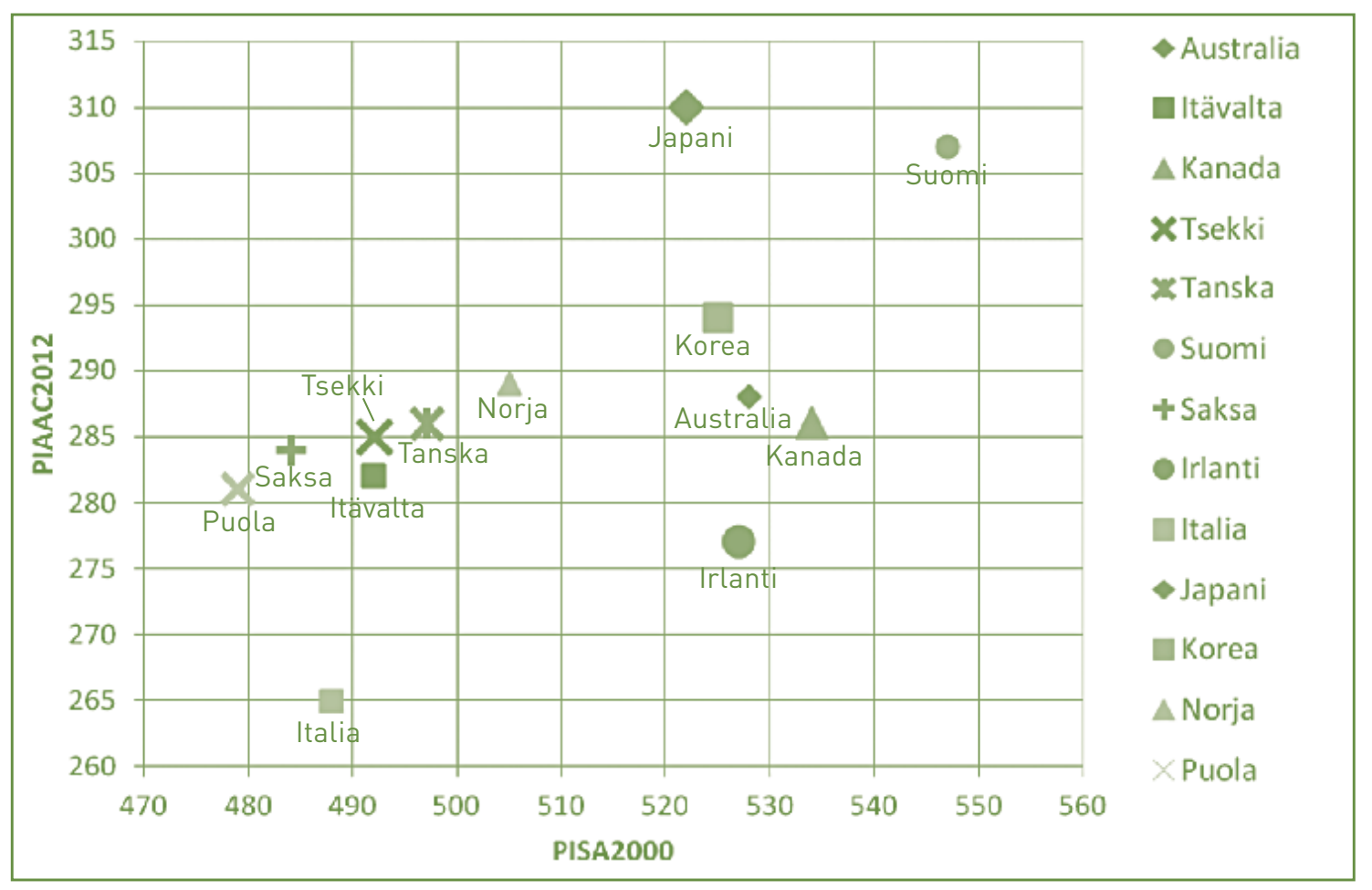

Taulukko 6. Aikuiskoulutukseen osallistumisen todennäköisyys (odds ratio) vuoden aikana lukutaidon tason mukaan suhteutettuna lukutaitotestissä alle 1 -tason suorittaneiden osallistumiseen (kun lukutaidon taso alle $1, \mathrm{OR}=1.0$ )

Odds ratioiden laskemisessa otettu huomioon sukupuoli, ikä, koulutustaso ja työmarkkina-asema.

Lähde: OECD 2013, taulukko A5.8(L).

\begin{tabular}{|c|c|c|c|c|c|c|c|c|}
\hline & & & & & & & & $4 / 5$ \\
\hline & OR & $\mathrm{p}$-arvo & OR & $\mathrm{p}$-arvo & OR & $\mathrm{p}$-arvo & OR & p-arvo \\
\hline Saksa & 2,0 & 0,073 & 3,1 & 0,003 & 4,8 & 0.000 & 7,8 & 0,000 \\
\hline Korea & 1,6 & 0,121 & 2,2 & 0,009 & 3,3 & 0,000 & 5,3 & 0,000 \\
\hline Kanada & 1,5 & 0,029 & 2,1 & 0,000 & 3,4 & 0,000 & 5,2 & 0,000 \\
\hline Australia & 1,6 & 0,177 & 2,1 & 0,012 & 3,2 & 0,000 & 5,0 & 0,000 \\
\hline Slovakia & 1,4 & 0,538 & 1,8 & 0,233 & 2,7 & 0,059 & 4,8 & 0,007 \\
\hline Espanja & 1,6 & 0,010 & 2,0 & 0,000 & 2,8 & 0,000 & 4,6 & 0,000 \\
\hline Puola & 1,9 & 0,087 & 2,4 & 0,012 & 3,4 & 0,001 & 4,5 & 0,000 \\
\hline Viro & 1,4 & 0,305 & 1,7 & 0,072 & 2,3 & 0,005 & 3,9 & 0,000 \\
\hline Tanska & 1,3 & 0,174 & 2,0 & 0,000 & 2,6 & 0,000 & 3,8 & 0,000 \\
\hline Keskimäärin & 1,2 & 0,043 & 1,5 & 0,000 & 2,2 & 0,000 & 3,1 & 0,000 \\
\hline Yhdysvallat & 1,2 & 0,431 & 1,4 & 0,183 & 2,1 & 0,008 & 3,1 & 0,002 \\
\hline Englanti & 1,3 & 0,476 & 1,5 & 0,178 & 2,0 & 0,023 & 2,9 & 0,001 \\
\hline Japani & 1,2 & 0,773 & 1,6 & 0,476 & 2,0 & 0,285 & 2,7 & 0,150 \\
\hline Ruotsi & 1,0 & 0,992 & 1,5 & 0,063 & 2,0 & 0,004 & 2,6 & 0,000 \\
\hline Suomi & 1,0 & 0,998 & 1,3 & 0,416 & 1,7 & 0,108 & 2,3 & 0,021 \\
\hline Italia & 0,8 & 0,537 & 1,0 & 0,962 & 1,7 & 0,102 & 2,1 & 0,083 \\
\hline Pohjois-Irlanti & 0,9 & 0,786 & 1,2 & 0,677 & 1,5 & 0,416 & 2,1 & 0,194 \\
\hline Irlanti & 0,9 & 0,786 & 1,2 & 0,677 & 1,5 & 0,416 & 2,1 & 0,194 \\
\hline Tsekki & 0,9 & 0,881 & 1,2 & 0,789 & 1,6 & 0,485 & 2,1 & 0,204 \\
\hline Belgia & 1,1 & 0,807 & 1,3 & 0,372 & 1,7 & 0,064 & 1,8 & 0,065 \\
\hline Norja & 1,0 & 0,890 & 1,2 & 0,493 & 1,6 & 0,063 & 1,5 & 0,072 \\
\hline Kypros & 1,0 & 0,994 & 0,9 & 0,888 & 1,1 & 0,886 & 1,3 & 0,646 \\
\hline
\end{tabular}


vaiheessa. Aineiston saaminen tutkimuskuntoon on vaatinut runsaasti tarkkaan pohdittuja ratkaisuja. Kaiken kaikkiaan esitelmät lujittivat luottamusta aineiston pätevyyttä kohtaan. Erityisesti ETS:n (Educational Testing Service) Kentaro Yamamoton luento PIAAC-aineiston mahdollisuuksista alueellisten estimaattien kehittämiseen ja sitä seurannut David Kaplanin kommenttipuheenvuoro avasivat kiinnostavia näkymiä niin kutsuttujen "pienempien alueiden" (small areas, sub-populations) taitotason arviointiin.

Kun PIAAC-aineiston perusteella tiedetään, millä tavalla erilaiset taustatekijät (ikä, koulutustaso, sukupuoli, ammatti, työn ominaisuudet jne.) ovat yhteydessä taitoihin, voidaan vastaavat taustatiedot kattavien rekisteriaineistojen perusteella laatia estimaatteja pienempiä alueiden taitotasosta ilman testien suorittamista. Yamamoto on kokeiluestimoinneillaan onnistunut pääsemään hyvin lähelle havaittuja eli testituloksiin perustuvia,"todellisia" jakaumia.

Heikki Silvennoinen

kasvatustieteen professori

Turun yliopisto
LÄHTEET.

Linnakylä, P., Malin, A., Blomqvist, I. \& Sulkunen, S. 2000. Lukutaito työssä ja arjessa. Aikuisten kansainvälinen lukutaitotutkimus Suomessa. Jyväskylän yliopisto. Koulutuksen tutkimuslaitos.

Malin, A. 2012. Kansainvälinen aikuistutkimus arvioi väestön perustaitoja. Aikuiskasvatus 32 (2), 129-136

Malin, A., Sulkunen, S. \& laine, K. 2013. PIAAC 2012. Kansainvälisen aikuistutkimuksen ensituloksia. Opetus- ja kulttuuriministeriön julkaisuja 2013:19. Helsinki: OKM.

OECD 2012. Literacy, Numeracy and Problem Solving in Technology-Rich Environments: Framework for the OECD Survey of Adult Skills. Paris: OECD Publishing.

OECD 2013. OECD Skills Outlook 2013: First Results from the Survey of Adult Skills. Paris: OECD Publishing.

Simola, H.; Rinne, R.; Varjo, J. \& Kauko, J. 2013. The Paradox of the Education Race: How to win the ranking game by sailing to headwind. Journal of Education Policy 28(5), 612-633.

Välijärvi, J. 2010. PISA - koulun kehittämisen työkalu vai kasvavan taloudellisen kontrollin ilmentymä? Teoksessa R. Laukkanen (toim.) PISA, PIAAC, AHELO. Miksi ja miten OECD mittaa osaamista? Opetus- ja kulttuuriministeriön julkaisuja 2010:17. 33-39. Helsinki: Opetus- ja kulttuuriministeriö. 